\title{
PRODUCTION OF SPACE, TRANSFORMATIONS OF CAPITALISM AND THE REAL ESTATE STRATEGIES OF RETAIL COMPANIES
}

\author{
https://doi.org/10.4215/rm2020.e19004 \\ Cláudio Smalley Soares Pereira a $^{*}$
}

(a) Dr. in Geography. Professor at the University of Pernambuco (UPE), Petrolina (PE), Brazil.

ORCID: https://orcid.org/0000-0002-4624-4057. LATTES: http://lattes.cnpq.br/3198754128199522.

Article history: Received 14 October, 2019 Accepted 21 December, 2019 Publisher 15 February, 2020
(*) CORRESPONDING AUTHOR

Address: UPE, Rodovia BR 203, Km 2, S/N, Cep: 56328-900, Petrolina (PE), Brasil. Tel: (+55 87) 3866-6468.

E-mail: clasmalley@hotmail.com

\begin{abstract}
This paper aims to analyze the current transformations of commercial capital in contemporary capitalism. In light of the dynamics of globalization, retail commercial capital has changed its actions and strategies, based on the prevailing logic of the functioning of the capitalist economy in the current period. The study examines the global expansion of retail, as well as its territorial consequences, and gives particular emphasis to the role of financialization and real estate business in these dynamics. Finally, we highlight how both foreign and domestic retail companies began to view real estate investment as a means of obtaining profitability that contributes to economic reproduction.
\end{abstract}

Keywords: Contemporary Capitalism, Commercial Capital, Retail, Real Estate Strategy.

\section{Resumo / Resumen}

PRODUÇÃO DO ESPAÇO, TRANSFORMAÇÕES DO CAPITALISMO E ESTRATÉGIAS IMOBILIÁRIAS DAS EMPRESAS VAREJISTAS

O propósito deste artigo é analisar as transformações contemporâneas do capital comercial no capitalismo contemporâneo. Compreendemos que à luz das dinâmicas da globalização, o capital comercial varejista modificou suas atuações e estratégias, recorrendo às lógicas preponderantes do funcionamento da economia capitalista no período atual. Analisa-se a expansão global do varejo, bem como suas consequểncias territoriais e, com uma maior ênfase, indaga-se sobre o papel da financeirização e dos negócios imobiliários nessas dinâmicas. Destacamos, por fim, que as empresas varejistas, de capital estrangeiro e nacional, passaram a vislumbrar no investimento imobiliário uma forma de obtenção de rentabilidade que contribui para a reprodução econômica.

Palavras-chave: Capitalismo Contemporâneo, Capital Comercial, Varejo, Estratégia Imobiliária.

\section{PRODUCCIÓN DEL ESPACIO, TRANSFORMACIONES DEL CAPITALISMO Y ESTRATEGIAS INMOBILIARIAS DE EMPRESAS} MINORISTAS

El propósito de este artículo es analizar las transformaciones contemporáneas del capital comercial en el capitalismo contemporáneo. Entendemos que, a la luz de la dinámica de la globalización, el capital comercial minorista ha cambiado sus acciones y estrategias, utilizando la lógica predominante del funcionamiento de la economía capitalista en el período actual. Analizamos la expansión global del comercio minorista, así como sus consecuencias territoriales y, con mayor énfasis, preguntamos sobre el papel de la financiarización y el negocio inmobiliario en estas dinámicas. Finalmente, destacamos que las empresas minoristas, tanto extranjeras como nacionales, comenzaron a ver la inversión inmobiliaria como una forma de obtener rentabilidad que contribuya a la reproducción económica.

Palabras-clave: Capitalismo Contemporáneo, Capital Comercial, Comercio Minorista, Estrategia Inmobiliaria. 


\section{INTRODUCTION}

The dynamics of contemporary capitalism have placed the production of space at the center of society's attention. Over the last five decades, discussions about the spatiality of social life have predominantly been academic, scientific and philosophical in nature. However, there is evidence that space seems to have simultaneously entered political, socioeconomic and even cultural discussions, further qualifying proposals for understanding and even intervening in territory. The spatial strategies of capitalist companies from various economic sectors, including real estate businesses and retailers, also fall into this equation. This article focuses on the strategies of the latter two groups of companies.

We understand the importance of making the links to theoretical frameworks clear to the reader by expressing a form of analytical understanding of how the world functions, as well as a way of imagining how this world can be overcome. This study starts from the idea of the production of space, according to the conceptualization of Henri Lefebvre (2000), for whom space is a social and historical product, as well as a condition and means through which society becomes possible, that is, space is the "mode of existence of social relations" (LEFEBVRE, 2000, p. 152). Thus, within its historical and social dimensions, our emphasis is on the production of space under the capitalist mode of production.

The above poses the question of why, if space is socially produced, so many agents adopt conflictive relationships that are full of contradictions in the context of capitalism. Lefebvre (2015) argues that these agents can be understood at the levels of "macro-decisions" and "micro-decisions". Thus, according to Lefebvre (2015, p. 448-449), "politicians, technocrats and planners, the military, financiers, local authorities, construction workers, and 'users"' and "urban social movements [...], architects and urbanists", intervene and produce "in a joint and disjointed way the homogeneous and broken space", constitutive and characteristic of capitalism. The agents who produce spaces for commerce and consumption join this contradictory process.

This study's methodological approach uses several available sources, notably material from the specialized press and the websites of the companies analyzed here, including their annual reports and balance sheets, although the content, presentation, organization, and disclosure of the information of latter is not uniform. Nevertheless, it is essential information and data which is balanced by other sources, including interviews that were published in the press. Prominence is given to the actions of Carrefour and the Companhia Brasileira de Distribuição (CBD), as in addition to being the largest retail companies in Brazil they have also invested in real estate on a national and international scale for some years and their investment data is available in their annual reports. It is important to note that all information involving monetary values (earnings, shares, rents) refers to nominal values, available from the various sources consulted.

Retailing in Brazil has modernized in recent decades, leading to the reorganization of the country's commercial and consumer geography. The Brazilian socio-spatial formation (SANTOS, 1977, 1978) has strikingly articulated with the dynamics of capital accumulation on a global scale and has become the focus of investments by capitalists from other countries. Large retailers have contributed by injecting new economic and social dynamics into cities, regions, and places that were previously outside of their spatial and economic strategies Even whilst this article focuses on the economic and spatial dynamics and strategies on a national scale, we have no doubt that these processes also cross and redefine urban space, spatial practices, and everyday life, since, from a multiscale point of view, they touch on a fundamental point in the production of space, namely, spaces for commerce and consumption and social and individual reproduction in cities.

This article presents some results of a study that focused on the relationship between retail and real estate from a wide perspective, using certain specific companies as an example. The primary goal is to show that retail capital is mobilizing land and real estate, and therefore space, for its economic reproduction.

\section{THE GLOBAL TRANSFORMATIONS OF THE RETAIL TRADE IN CONTEMPORARY CAPITALISM}

In his book on democracy, the Franco-Algerian philosopher Jacques Rancière (2015) states that 
we live in an "age of hypermarkets". This era, the fruit of Fordism and widespread distribution, is now combined with "a mass individualistic society", in which the consumer, eager for goods, is confused with democratic man. Democracy seems to be the democracy of consumption and thus, in a way, a tyranny, the tyranny of the market. Why? Because the law that reigns in the contemporary world is "the law of capitalist profit" that operates under the control of a "financial and state oligarchy" in which "state power and the power of wealth tend to come together in a single specialized [and spatialized!] management of cash flows and populations" (RANCIÈRE, 2015, p. 120). Such a dynamic is nothing less than what has been conventionally called globalization by some and, more critically, the globalization of capital by others.

In this sense, Harvey's (2004) contribution is significant. Globalization is a new phase in the capitalist production of space, which, on a global scale, involves consequences and contradictions that modify the geographical landscape around the world through unequal geographical developments (HARVEY, 2004). This interpretation clarifies that the space produced by capitalism in the contemporary world, including retail companies' spatial and economic actions and strategies, is related to a series of aspects specific to this period, including financial deregulation, urbanization, new modes of consumption, new roles for nation-states, and the information and communication revolution.

In the particular case of commercial capital, economic globalization and the insertion into national markets that have redefined territories and places in recent decades can be divided into distinct periods. The first of these involved the internationalization of large retailers in the last quarter of the twentieth century. One example is Carrefour's entry into the Brazilian market in 1975. A second moment occurred in the 1990s, preceded by the expansion in previous years of the domestic markets of each company's country of origin. The international expansion of the 1990s was undoubtedly unmatched by the earlier one in terms of scale, scope and speed, with a concentration of capital and increasing power in the hands of these companies (COE; WRIGLEY, 2017). In the 1990s, great investment opportunities in the so-called "emerging markets" arose through the expansion of foreign direct investment (FDI), which reflected the territories' economic dynamics, with rebates in sales and corporate profits. The weight of the foreign markets is remarkable and says a lot about the globalization of retail companies (Figure 1).

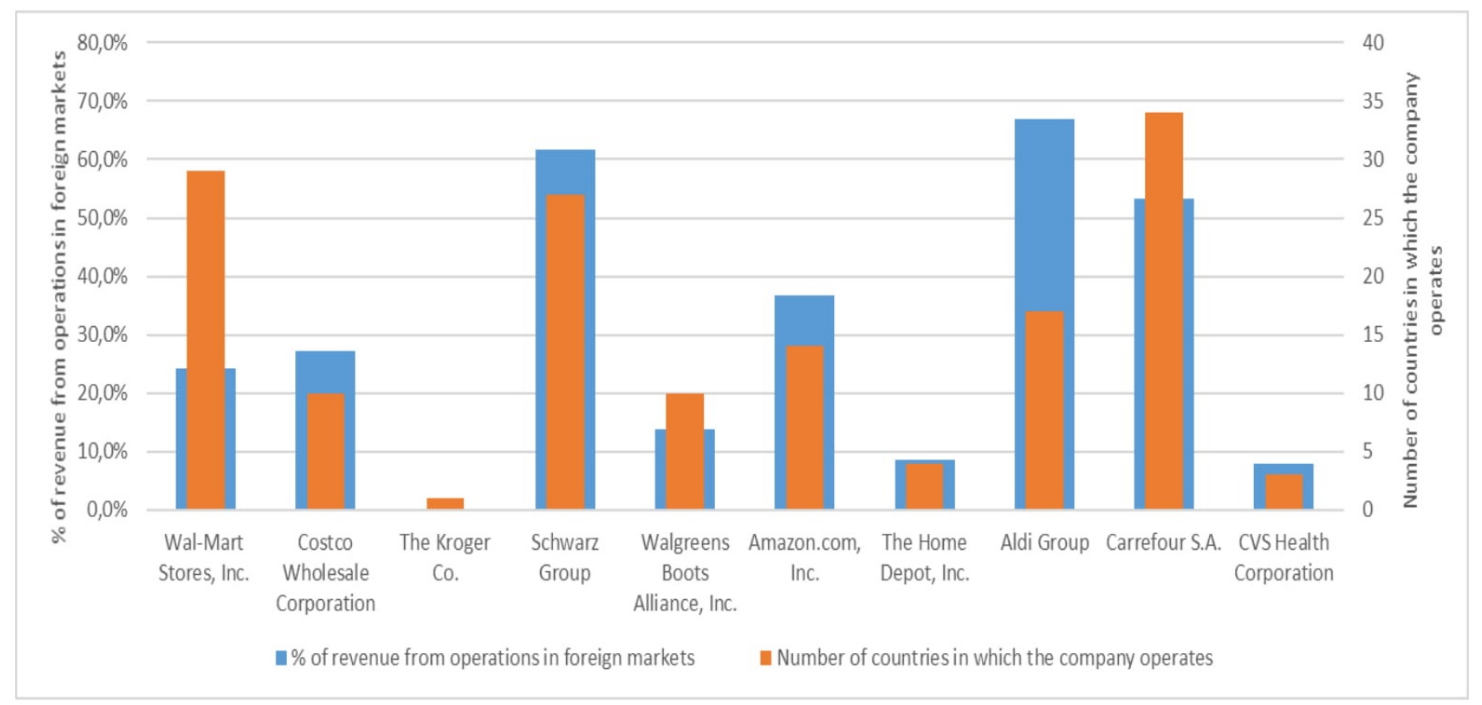

Figure 1 - The role of foreign markets in the operation and revenue of the world's 10 largest retailers (2016). Source: Deloitte, Global Powers of Retailing, 2018. Prepared by the author.

Operations by transnational retail corporations in various national markets show how fruitful the path of internationalization has been for many companies in terms of increased profits and economic growth. The challenges of an internationalization strategy include going to other countries, entering markets with local competition, and adapting (or not) to the culture of particular socio-spatial formations. According to several rankings, such as Ibevar (2019) and "The 1000 Largest" of the Valor Econômico newspaper, Carrefour is currently the largest retailer operating in Brazil. In 2016, the former 
CEO of the company Georges Plassat described Brazil as a "beautiful business" to Valor Econômico $(10 / 03 / 2017)$. Graph 1 shows that more than $50 \%$ of the French giant's revenue comes from foreign markets; Brazil is one of its largest markets outside France. This strategy becomes a global logic that reorganizes national territories in the context of a competitive logic between companies in the global market. Increasingly this produces territorial and economic unification, and spatial fragmentation and differentiation, in a contradictory process in which the State, the country, becomes its base of action, which is referred to as a "national space of the international economy" (SANTOS, SILVEIRA, 2001).

Between the 1990s and the early 2000s, a third period is characterized by shrinkage of corporate sales and the need to focus on strategic markets, followed nowadays by the fourth period of global retail expansion focused on investments in e-commerce. This trend, which has been gaining ground since the 1990s and consolidated itself in the 2000s, is exemplified by Amazon's ranking among the top ten global retailers of 2016, according to the Deloitte 2018 Global Powers of Retailing report.

Coe and Wrigley (2017) argue that after the 2007-2008 crisis the focus of internationalized distribution shifted under the induction of the Internet, which can be characterized as a new era of globalized distribution or, in the authors' words, a "retail revolution." For Moati (2009), this is a new Internet-based commercial revolution in services and communication that redefines commercial spaces, retail, and modes of consumption. Several companies perceive this virtual alternative as a strategy of economic and performance reorganization, since, among other things, e-commerce helps to reduce costs in many sectors, such as physical work and stores.

According to Global Powers of Retailing, between 2006 and 2016, Europe and North America lost retail revenue positions among the largest companies in the industry, while Asia / the Middle East, East Asia and Latin America increased their respective share of revenue in one decade. However, although there may be a general idea that companies have been "successful" in finding new markets, the particular experiences of certain companies have resulted in divestment, failure, and the desertion of markets that they had previously entered (DURAND, 2011; COE, WRIGLEY, 2017).

The clearest example of this process is Carrefour's withdrawal from Asian countries such as Malaysia and the Philippines, from Latin America, such as Colombia, and from Europe, in the case of Greece (BENQUET, DURAND, 2016). More recently, the French chain, which had been operating in China since 1995 , sold $80 \%$ of the company to Suning.com, a local retailer with the third-largest online sales platform in the country and almost 9,000 stores in 700 cities. In Brazil, the most notable example in this regard is Walmart, which initiated a restructuring plan in recent years resulting in the closure of hundreds of stores in the country, and the eventual sale of $80 \%$ of its stake in Brazilian operations in 2018 to the private equity fund Advent International, which has investments in various sectors in over 30 companies in Brazil .

In conjunction with these recent changes and alongside investment in e-commerce, a retail financialization process has developed that resizes corporate actions and operations, modifying the actions and strategies of commercial capitalists. Here financialization is understood as the present moment of capitalism, where financial accumulation predominates. We agree with Chesnais (2005) that in contemporary capitalism financial capital superimposes other capitals in the accumulation process. Thus, there is a predominance of financial accumulation, understood as the "centralization in institutions of non-reinvested industrial profits and unconsumed incomes, which have the task of valuing them as investments in financial assets - currencies, bonds and stocks - keeping them outside the production of goods and services "(CHESNAIS, 2005, p. 57). In this sense, "the big banks, the big insurance companies, the investment funds and the treasuries of the big industrial groups are their organizational forms" (CHESNAIS, 2018, p. 1). This capitalism works on an international scale with capital flows that favor some places over others. Since the 1970s the State has played a role by facilitating such flows through the liberalization of the financial markets (CHESNAIS, 2005).

Baud and Durand (2011) analyzed the impact of financialization on retail companies between the 1990s and 2010s and showed that since 2003 this process has been increasing in companies in parallel with a slowdown in sales and in the context of divestment that includes changes in their relationships with suppliers and customers. According to Baud and Durand (2011) this combination of organizational arrangements benefitted major retailers by providing them with dynamic gains and high levels of financial profitability. The role of retail financialization has consequences that go beyond the 
reorganization of operations in socio-spatial formations around the world. However, financialization does not benefit all corporations and can be active in the economic decline of groups, as in the case of Carrefour (BENQUET, DURAND, 2016).

Furthermore, financialization within retail and commercial and service companies can be seen from a range of operations such as banks and credit cards, as well as investment funds holding shares in corporations. In Brazil, this process is quite recent and constitutes a "national financial retail", which includes various types of retailers, such as Marisa, Pernambucanas, Hering, Renner, Arezzo \& Co., Guararapes and Restoque stores (SALTORATO et al, 2016).

The companies' entry into the financialization process was one factor contributing to their decline. Philon (2005) demonstrated how entering the era of financial accumulation weakened large French companies, which were left at the mercy of financial agents' control and decisions. This reinforces Chesnais's (2005, p. 37) analysis that from the 1980s onward in the US, and 1990s in Europe "it was not only part of companies' property that became progressively more tradable financial assets on the stock market, but also the companies themselves and even entire industrial groups."

The financial agents' voraciousness is already well known in the literature (cf. CHESNAIS, 2005), and the dictates of the power of finance in the accumulation process, as a particularity of contemporary capitalism, cannot be overlooked when investigating retail commercial capital. Fortunately, some studies have problematized the role of retail financialization in recent years, from various perspectives (BAUD, DURAND, 2011; BENQUET, DURAND, 2016; SALTORATE et al, 2016; WRIGLEY, WOOD, 2018). This is of such importance that when Walmart's operations in Brazil in 2018 and Carrefour's operations in China in 2019, mentioned above were realized almost instantly the shares of these and other retailers rose on the stock markets.

Benquet and Durand (2016) showed that the financialization of large-scale distribution is part of the era when this kind of distribution went through a crisis, favoring the restructuring of companies that prioritize share values and financial logic to the detriment of investments in production and traditional operations.

Carrefour appears in Benquet and Durand's (2016) analysis as an example of how the financialization of large-scale distribution was accompanied by the company's economic decline. Compared to Tesco (Great Britain), Walmart (USA) and Casino (France), Carrefour's shareholding restructuring reveals that its trajectory and insertion into financialization damaged the firm, both as regards profits and returns, as well as the payment of wages. The change and restructuring of the company resulted in a transformation of its corporate governance, with the entry of Blue Capital investment fund in 2007 as a major shareholder. The pursuit of ever-faster profits to pass on to "impatient shareholders" weakened the company because jobs and wages were negatively affected to pay shareholders, resulting in strikes. The company has had to narrow the perimeter of its explorative operations, that is, its area of activity in foreign markets.

This point is extremely pertinent. Benquet and Durand (2016) show how, in addition to the reformulations in the capital-labor relationship that negatively impacted workers, the need to satisfy "impatient shareholders" meant Carrefour had to divest itself of holdings in operations in some countries. In early 2010, and between 2011 and 2012, the company sold assets and withdrew from Greece, Singapore, Colombia, Malaysia and Indonesia. In addition, it approved the separation of the Dia network (which was a victory of the investment funds that sought to restructure the company and sell assets, including in Brazil, in a true demonstration of the power of financial logic). As a result, the company "needed to give up an important part of its real estate assets to free up cash" (BENQUET, DURAND, 2016, p. 50). Thus, the disposal of real estate assets is crucial evidence of how real estate has become relevant in companies' economic dynamics. Retaining, controlling or selling them are forms of real estate management that can reflect on the groups' operating results.

The following section analyses the relationships between the retail trade and0 real estate dynamics. This type of investment is new to retail business capital as a whole, which previously neither operated nor invested in the real estate business. Building shopping centers, remodeling hypermarkets to receive real estate rents, buying land and then renting it out, establishing partnerships with construction companies and developers, and creating subsidiaries only to administrate the group-owned real estate is something quite contemporary that has caught the attention of some researchers. 
(MÉRENNE-SCHOUMAKER，NAPPI-CHOULET，2014; DESSE，MADRY，WAYNES，2016; PEREIRA, 2018, 2019). This is a fairly recent strategy, and just like financialization and e-commerce, it should be better analyzed and investigated, as it involves several relationships that put the social production of space at the center of the debate.

\section{THE RETAIL TRADE AND REAL ESTATE INVESTMENTS}

Retail commercial capital has sought to modify its economic and spatial strategies in various socio-spatial formations. Carrefour and the Companhia Brasileira de Distribuição (CBD) turned their attention to the real estate business and in the $2000 \mathrm{~s}$, both companies created their real estate sectors. In Europe, Carrefour created its real estate division, called Carrefour Property in 2004, whilst the Brazilian version, Carrefour Property Division, started functioning at the beginning of this decade. Overall, the real estate division operates in ten countries across Europe, Asia and Latin America (Brazil, France, Spain, Italy, Argentina, Belgium, Poland, Romania, China and Taiwan), associated with the Europe-specific Carmila, a company in the group that specializes in revitalizing hypermarkets and shopping malls. In 2010, Carrefour's real estate assets were valued at 17.2 billion euros, according to the company's own document Journée Investisseurs (CARREFOUR, 2011, p. 8).

The group's real estate interests were already clear and were widely reported in the specialized press. A few years ago, the Financial Times published the article "Carrefour: back to the future" that was translated in Brazil by the newspaper Valor Econômico (12/18/2013) under the title "A nova lógica do Carrefour na França (The new logic of Carrefour in France)", highlighting the French retailer's intended strategy, which can be summed up in a nutshell: expanding real estate equity. The Financial Times pointed out that in the previous decade part of the real estate assets had been sold to the real estate management company Klépierre, which operates in Spain, France, and Italy. Ten years later, Carrefour would buy back the malls in an operation involving 127 shopping centers worth two billion euros at the time. In addition to restoring the real estate assets, the aim was "to help the company revive its European hypermarkets" .

Real estate strategies through the acquisition of shopping malls, restructuring hypermarkets and buying land have also been reported in the Brazilian press since the late 2000s and are part of the Property Division. Property's focus is the "management of arcades, the administration of our properties and the creation of real estate solutions that reinforce our stores and make our spaces profitable". The Definitive IPO on the São Paulo Stock Exchange on July 18, 2017, described the performance of the real estate division as follows:

Our property division also manages our store modernization and renovation initiatives, coordinating and executing development projects and construction works, and also has the important task of optimizing our property portfolio and creating value by increasing the potential of our properties, including through partnerships with third parties in some projects, with the main objective of increasing consumer movement and satisfaction in our stores (CARREFOUR, PD, 2017, p. 560).

Carrefour owns more than 15 million square meters in Brazil, with $308,000 \mathrm{~m}^{2}$ of GLA in 150 arcades and three shopping malls, with a total number of 2028 of leases. In 2017, the operating income from real estate leases was $\mathrm{R} \$ 241.3$ million, according to the company's financial report (CARREFOUR, 2018). One example of this strategy was the Villa Lobos hypermarket in São Paulo, where the space occupied by the hypermarket was reduced from 7,969 $\mathrm{m}^{2}$ to $5,606 \mathrm{~m}^{2}$, and a Decatlhon unit was installed. As a result, the flow of customers increased by $15 \%$ and hypermarket's sales by $30 \%$. According to Yen Wang, the executive director of Carrefour Property in Brazil, "this did not include Decatlhon's additional rent and the shared property tax for the condominium. This is a very powerful model that we are working to replicate".

Carrefour's operating logic is divided into three segments: the first is called Atacadão, bearing the name of the company acquired by the French retailer in 2007 and is its flagship in Brazil. In 2018 its gross revenue was $\mathrm{R} \$ 37.6$ billion. Retail is the second segment, encompassing all other store formats, 
including hypermarkets, supermarkets, the Carrefour Market mini markets, which are expanding, and even gas stations. Finally, Financial Solutions is the group's third segment dealing specifically with financial operations that involve offering credit solutions, credit cards and product insurance to consumers. In the latter, Carrefour operates in a strategic partnership with Banco Itaú Unibanco, through Banco Carrefour, in which it holds 51\% of the share capital. In 2017, the three segments accounted for $62 \%, 34 \%$ and $4 \%$ of the net revenue share, respectively (CARREFOUR, 2018). It is in the second segment where the various commercial formats and types of stores operate that the group's real estate operations are highlighted.

Figure 2 shows the distribution of stores by type of property and it is clear that Carrefour owns most of these, in fact, more than $70 \%$ of the spaces where the company develops its activities in the Brazilian territory belong to the company and the rest are rented. For the company, control of its real estate assets is fundamental to its competitive market strategy, giving it greater decision-making power over investments, facilities, renovations and store expansions, and even the sale of certain units (CARREFOUR, PD, 2018, p.560). The Pão de Açúcar Group, in turn, has the opposite approach and only possesses approximately $20 \%$ of the properties where its stores operate.

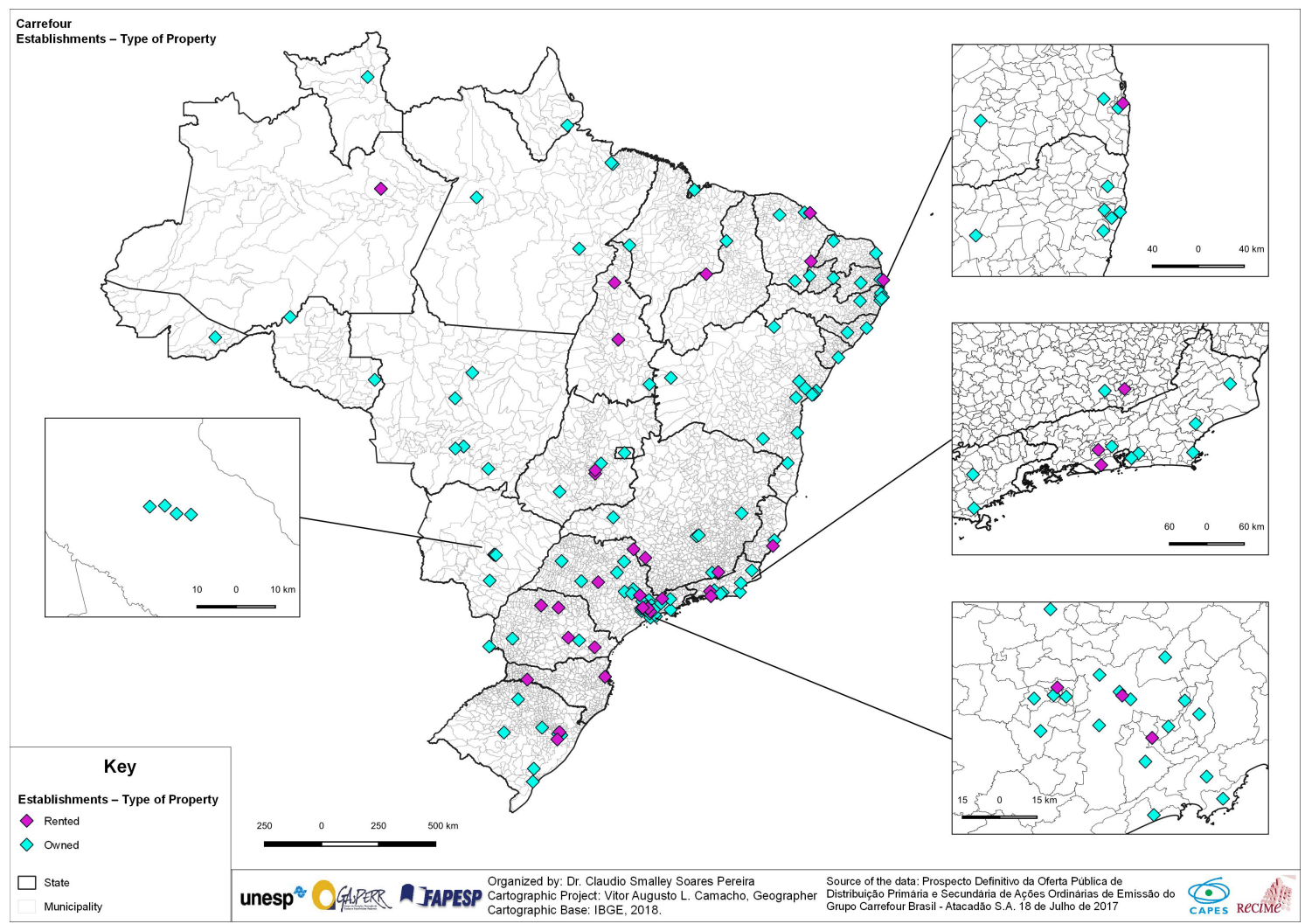

Figure 2 - Brazil. Spatial distribution of Carrefour stores by property type (2017).

Besides remodeling their hypermarkets by reducing the sales space (an ongoing strategy that is also present in the investment plan "CARREFOUR 2022: a new ambition for the group", launched in January 2018 and focused on e-commerce) other company strategies can be identified:

(i) The transformation of hypermarkets into shopping malls, a strategy that took place both in Europe and Brazil. For some years, the Brazilian press (for example, ESTADÃO, 12/1/2014) has been reporting how these trends are transforming hypermarket spaces and Carrefour's construction of shopping malls. In the Jardins neighborhood in São Paulo, the Pamplona Hypermarket was converted into a mall. According to the former president of the group's real estate division, it is a " $100 \%$ Carrefour venture $[\ldots]$ the group's largest investment in the world in a single project". The five-story mall has 80 stores and is over $18,000 \mathrm{~m}^{2}$. This strategy is a joint venture with large construction companies, in this case, Odebrecht Realizações Imobiliários. These associations with major builders are also visible in the spatial actions of the GPA Mall Properties. To build the Pamplona and Butantã shopping malls, both in 
São Paulo, the company transferred $\mathrm{R} \$ 333$ million to cover the land and construction of both projects. This reclassified the property type from a real estate asset to an investment property, which generates rental income. The value of these investment properties rose from $\mathrm{R} \$ 159$ million in 2016 to $\mathrm{R} \$ 478$ million in 2017.

(ii)In-store advertising and marketing by other companies also generate income from the use of space. These commercial, service, and even, industrial companies need publicity to make their activities and brands visible. They do so by renting various spaces at Carrefour stores, including gates, food court tables, parking lots, and signage.

(iii) The company also intends to develop real estate projects that go beyond commercial spaces. We show above how it articulates with construction companies, and there are projects that even aim to build residential spaces as a way to optimize, value and extract profitability from real estate and land assets. This would, therefore, be a fourth strategy that places space, land and real estate in the company's economic reproduction plan.

How much, in fact, is the revenue that rents provide the group? These questions are not easy to answer as the data is not always disaggregated. In the French and Portuguese reports, revenue from rentals is accounted for in the Retail segment under "other income" . In 2018, Carrefour Property division's net operating revenue was R $\$ 202.9$ million, derived from real estate leasing (less than 2016 and 2017 , which were $\mathrm{R} \$ 241.3$ million and $\mathrm{R} \$ 216.1$ million, respectively), which corresponds to approximately $0.5 \%$ of the group's net operating revenue (CARREFOUR, 2019). This may not seem very significant, especially if we bear in mind that almost all of the revenue comes from the circulation and distribution of goods. What is important, however, is to note that this is a strategy that has been gaining ground in the company's operations.

The Brazilian Distribution Company (CBD) is controlled by the Pão de Açúcar Group (GPA), which has been owned by the French Casino group since 2012 and has followed a fairly similar pattern to Carrefour. It opened its real estate subsidiary, GPA Malls Properties in 2009 , and perceived this real estate strategy as a way to profit from arcades, leases to traders and franchises, etc. As well as renting out space, their strategy is notable for their articulation with construction companies to build residential and commercial complexes, so that they earn rent from land due to their participation in the process as the landowner. This strategy is also used by Carrefour.

On the GPA Malls Properties website, which gives information about the company's operations, partnerships, and so on, it says that the idea is to "transform spaces into opportunities". A short text presenting the group's real estate division, taken from its official page, is reproduced below:

Turning spaces into opportunities

Welcome to GPA Malls! We are the real estate unit of the Pão de Açúcar Group, responsible for managing the commercial spaces and expanding the stores of our Extra, Pão de Açúcar and Assaí chains. Our work is based on an entrepreneur-entrepreneur relationship, to offer you the best structure and services to grow your business or franchise and increase your profitability. At GPA Malls, you can choose from a variety of space options to suit your wishes and needs. Our commercial arcades are designed to provide the best experience for retailers and consumers with comfort, easy access, security and the convenience of having everything at your fingertips in one place. No matter the segment or size of your enterprise, we have the ideal area for your business. We also offer media options for brands that reach a high number of consumers at the moment of purchase. Also, our exclusive parking lots are available for rent to companies wishing to hold promotional activities and events. Throughout our history, we have signed more than 3,500 contracts with tenants and partners such as McDonald's, Itaú, Cinemark, Centaur, Petz, O Boticario, and other small and large brands. (our emphasis).

The quotation above shows that the operational logic is based on the use of spaces as a negotiable exchange value. Renting parking for businesses, leasing space in arcades, shops or kiosks, as well as the media, all offer opportunities for monetizing the spaces. It is also important to note that this type of operation is linked to the reproduction logic of other commercial capitalists, who often find a much cheaper price per square meter in these arcades, supermarkets and hypermarkets than in shopping malls. This is particularly interesting for franchises and results in a synergy of economic reproduction for both 
companies while reshaping the commercial geography of cities and spatial practices, as discussed by Pereira (2018).

In the words of Caio Mattar, former CEO of GPA Malls Properties the logic of "buying more land and creating more stores," (IG São Paulo, 10/06/2011) demonstrates the synergy between the real estate and retail businesses. The company's reports make it clear that this land acquisition strategy existed even before the creation of the real estate division. For example, a 1999 report on investment planning for the year 2000 states that "The Company will also strive to acquire land in strategic points, aiming at the continued organic growth of this [Hypermarkets] Division" (CBD, 1999, p. 12).

The company's investment plans for 2003 stated that "The volume of investments [for 2003] is estimated at $\mathrm{R} \$ 540$ million; $\mathrm{R} \$ 240$ million of which are allocated to opening new stores and acquiring strategic land [...] (CBD, 2002, p. 2). After the creation of the GPA Mall Properties, the investment in new stores and land acquisition in 2010, 2012 and 2013 was $\mathrm{R} \$ 350$ million, $\mathrm{R} \$ 703$ million and $\mathrm{R} \$ 785$ million, respectively (CBD, annual social report / 2013 - unaudited supplementary information, 2013, P. 1). In 2013, the company had 286 thousand square meters of GLA, an $18.4 \%$ rise from 2012 (CBD, 2013, p. 41). In 2011, the company had more than 1.5 million square meters of land in Brazil available for construction. Investments in land purchases have helped enhance its real estate operations in conjunction with the commercial dynamics that are the main focus of the company's operations.

According to Mérenne-Schoumaker and Nappi-Choulet (2014), both Carrefour and Casino's European strategies are linked to a process of the "financialization of real estate" on a global scale, which is evident in the transition and transformation of real estate assets into financial assets. According to the authors, this transition is due to the fact that more and more new agents, such as foreign investment funds, are now part of, and to a certain extent have taken control of, corporate governance. Thus, the arrival of new financial actors "has profoundly revolutionized [...] the real estate industry by financialising the commercial real estate market" (MÉRENNE-SCHOUMAKER, NAPPI-CHOULET, 2014, p. 200). The authors emphasize that

[...] rental real estate assets are held by companies that raise funds in the global capital market [...] real estate has become an asset like any other that allows investors to diversify the risks of their portfolios. The perimeter of finance now extends to real estate [...]. Commercial premises, which have become financial objects, are evaluated and requested by investors for rental income and the revenue from the liberated capital (MÉRENNE-SCHOUMAKER, NAPPI-CHOULET, 2014, p. 200).

Thus, in the context of financialization, the search for "outsourcing of operating real estate assets" (externalizations d'actifs immobiliers ), for example through sale and lease-back (as in the case of Casino with hypermarket real estate), has become a strategic tool for value creation by distribution companies. The increasingly evolving rental market is a financial asset that generates rent-based income and has added-value potential. This is occurring in an investment context marked by the growing presence of financial and international investors (NAPPI-CHOULET, 2003; MÉRENNE-SCHOUMAKER, NAPPI-CHOULET, 2014, p. 203-204).

Whether in the form of a real estate or financial asset, private land ownership retains its property status. It turns out that even when land and properties enter the financialization loop, they retain their patrimonial form, but change their quality. This means that real estate, formerly owned by a business or economic group as an asset from which an income could be extracted outside the financial markets and the logic of financial accumulation, has changed in quality with the emergence of new economic agents who have rights in the context of this new form of capital ownership. Real estate assets now generate income for economic agents beyond the company itself, and thus enter the more internationalized and global accumulation circuit. Institutional investors, investment funds and shareholders, who were previously absent from companies or fewer in number, have also become holders of this new form of capital ownership, taking the logic of income to a new level since they submit the company's operation to their dictates. Thus,

Property ownership creates the rights to revenue in the form of rents, land rents (urban or rural) and rent flows related to stock market investments. Its purpose is neither consumption nor wealth creation that increase production capacity, but "income" (CHESNAIS, 2005, p. 50). 
The shareholding restructuring of Carrefour analyzed by Benquet and Durand (2016), discussed earlier, is exemplary. The operation with Klepierre to recompose the real estate equity could only be achieved through a financial logic. With the operation, more than 800 thousand square meters of retail area and assets were valued at 2.7 billion euros, of which 1.8 billion were shares; of these, " 42 percent of the shares were held by Carrefour and the remainder by institutional investors" (REUTERS, $12 / 16 / 2013)$.

A report by IstoÉ Dinheiro (12/23/2009) demonstrated that a variety of companies were seeking to expand the real estate logic of their operations. The article also commented on Pão de Açúcar, McDonald's and Casas Bahia. Regarding the latter, the magazine reported on the real estate business gains resulting from the merger with Pão de Açúcar. At the time of the announcement, in 2009, Pão de Açúcar was expected to pay Casas Bahia R\$130 million per year until 2019 for the 513 stores. This would total $\mathrm{R} \$ 1.8$ billion in readjusted rental calculations. Another case was that of Abílio Diniz, who was still at Pão de Açúcar at the time. He says in the article that he rented twenty-eight of its thirty-two stores to Casino, which earned him R\$139 million in 2009. Currently, Abílio Diniz, now a Carrefour shareholder, continues to receive income from the store rentals to Casino through a real estate investment fund called Peninsula, which manages sixty-two of his stores that are all rented to Casino. These spaces generated Peninsula a profit of R \$217.4 million in 2014 (a year of GPA sales growth) and almost R\$ 212 million in 2016, 14.5\% more than in 2015. Between January and June 2017, the revenues were $\mathrm{R} \$ 167.4$ million, which was equivalent to the total of the whole of 2013 . The investment fund recorded a net gain of $88 \%$ in 2016 when compared to 2015 , equivalent to $\mathrm{R} \$ 278.7$ million . This particular example is an excellent illustration of the articulation between financialization and real estate.

The performance of Carrefour and GPA, as well as other companies, certainly attest to the importance of space. Obviously, space was already viewed as a particular type of capital accessible to companies, and here the internationalization process, understood strictly as spatial expansion to other places, regions and countries to increase profitability, is well-known. However, in the context of the operations analyzed in this study, the meaning that space, and therefore land and real estate, acquire is different. Space is used as exchange value in the context of divestments, falling sales, shrinking and international economic crisis, and certain markets being abandoned, which launched the internationalization and globalization process of retail to other levels.

Space and land have become salable and tradable commodities (LEFEBVRE, 2000), from which land and real estate rental income can be extracted, depending on how economic agents position themselves in relation to other capitals. Carrefour, for example, achieves profitability (also drained by the financial circuit) by renting spaces and through partnerships with construction companies. Thus, it plays a dual role: "commercial capitalist, because it is inserted in the dynamics of the distribution of goods, and landowner because it holds the land ownership rights acquired to operate distribution." (PEREIRA, 2019, p. 16).

Retailers need real estate to function; these properties do not always belong to landlords who simply live off the rent. Instead, they are often owned by companies that view leasing some of their space as a way to obtain fractions of socially produced added value. Many companies have employed this strategy, thereby redefining the logic of the commercial real estate market, urbanization and consumption. All of these topics are worthy of further investigation.

\section{CONCLUSIONS}

Given the above, three considerations appear to be feasible. First of all, understanding the global dimension of retail requires an analytical, conceptual and methodological arsenal that articulates multiple scales in the process of producing space. This means that business strategies of insertion into particular national markets with certain socio-spatial formations are related to globalized spatial selectivity and fragmentation, even as they bring about changes in modes of consumption, spatial practices and everyday life.

Secondly, the combinations and nexuses that modify contemporary capitalism and commercial capital (financialization, e-commerce, labor exploitation) need to be considered to understand the phenomenon. The complexity of the relationships involving retail and current capitalism are hard to 
understand, however, a methodological perspective that takes into account open and related totalities is an analysis that reveals the contradictions of the process. Nevertheless, even if this is not our central focus, a discussion of the global expansion of retail companies presupposes that the processes of financialization, economic restructuring, and State powers, as well as the widening of contradictions and class struggles in the field of labor and the production of commodities, are dimensions without which it is impossible to understand the movement that commercial capital has produced and continues to create in the capitalist production of space.

The final consideration is the role of real estate investments in transforming global retail. Evidently, rather than overvaluing a theme, this is a recognition of an important aspect of a multifaceted dynamic of contemporary capitalism. Real estate investments by retail companies involve the imbrication and conflict of interests of various fractions of capital (commercial, industrial and financial) around the production of space. It is worth stressing that real estate investment does not reduce the production of space to a triadic, complex and contradictory process as bequeathed by Lefebvrian theories. Rather, but it illuminates the strategies and actions of companies that have an important impact in determining the reproduction of inequalities in everyday life by monopolizing land and real estate in the city, the territory and the world.

\section{REFERENCES}

ASSALVE, D. Pão de Açúcar quer lucrar com imóveis. IG São Paulo, 06/10/2011. Disponível em: http://economia.ig.com.br/empresas/comercioservicos/pao-de-acucar-quer-lucrar-com-imoveis/n159725 9916848.html. Acesso em: 11 set. 2016.

BASILIO, P. Aluguel até 45\% mais barato atrai franquias para supermercados. Portal IG. 24/06/2013. Disponível em: https://economia.ig.com.br/financas/seunegocio/2013-06-24/aluguel-ate-45-mais-barato-atrai-franquiaspara-supermercados.html. Acesso em: 02 jun. 2016.

BAUD, C; DURAND, C. Financialization, globalization, and the making of profits by leading retailers. Socio-Economic Review, 10, 2012, p. 241-266.

BENQUET, M; DURAND, C. La financiarisation de la grande distribution. Restructuration de l'actionnariat et déclin économique du groupe Carrefour (1999-2013), Revue Française de Socio-Économie, n. 16, p. 37-59. 2016.

CARREFOUR. Prospecto definitivo da oferta pública de distribuição primária e

secundária de ações ordinárias de emissão do Grupo Carrefour Brasil, Atacadão S.A.

18 de julho de 2017. 822p. Disponível em:

https://www.goldmansachs.com/worldwide/brazil/areas-de-negocios/ipo/atacadao/final.pdf.

Acesso em: Acesso em: 15 set. 2017

CARREFOUR. Formulário de Referência 2018. Disponível em: https://www.grupocarrefourbrasil.com.br/Download.aspx?Arquivo=TKF+IZmsEHLMewxYEmjnXw== . Acesso em 5 jan. 2019.

CARREFOUR. Formulário de Referência 2019. Disponível em: https://www.rad.cvm.gov.br/ENETCONSULTA/frmGerenciaPaginaFRE.aspx?NumeroSequencialDocu mento $=89308 \&$ CodigoTipoInstituicao=2. Acesso em 26 dez. 2019

CARREFOUR. Journée Investisseurs. Presentation Carrefour Property. 17 mai. 2011. Disponível em: http://www.carrefour.com/sites/default/files/Investor_Day_17Mai_Introduction_Carrefour\%20FR.pdf. Acesso em: 19 set. 2019.

CHESNAIS, F. As dimensões financeiras do impasse do capitalismo. Revista Movimento. 3 mar. 2018. Disponível 
https://movimentorevista.com.br/2018/03/as-dimensoes-financeiras-do-impasse-do-capitalismo-mundial izacao-do-capital-chesnais/. Acesso em: 13 mai. 2018.

CHESNAIS, F. O Capital Portador de Juros: Acumulação, Internacionalização, Efeitos Econômicos e Políticos. In: CHESNAIS, François (org.) A Finança Mundializada: razões sociais e políticas, configuração, consequências. São Paulo. Boitempo Editorial, 2005. p. 35-67.

COE, N. M; WRIGLEY, N. Towards new economic geographies of retail globalization. In: CLARK, Gordon L.; FELDMAN, M. P.; GERTLER, M. S., WOJCIK, D.; KAISER, A. (eds.) The New Oxford Handbook of Economic Geography. New Edition ed. Oxford. Oxford Univeristy Press, 2017. p. 427-447.

COMPANHIA Brasileira de Distribuição (CBD), Resultados de 1999. Resultado do $4^{0}$ Trimestre de 1999. 13p.

COMPANHIA Brasileira de Distribuição (CBD), anuncia desempenho de vendas em Novembro de 2002 e Plano de Investimentos para 2003, 2002 2p.

COMPANHIA Brasileira de Distribuição (CBD), Relatório Anual e de Sustentabilidade 2013. 116p.

COMPANHIA Brasileira de Distribuição (CBD), balanço social anual/2013 - informações suplementares não auditadas, 2013.9p.

DELOITTE. Global Powers of Retailing 2018. Transformative change, reinvigorated commerce. Deloitte Touche Tohmatsu, 2018. 48p.

DESSE, R-P; MADRY, P.; WAYNES, B. Acteurs et opérateurs du commerce. Bulletin de la Société Géographique de Liège, vol. 66, n. 1, p. 45-50, 2016.

DIAS, Diogo. Pão de Açúcar cria divisão imobiliária. Supermercado Moderno. 09 jun. 2009. Disponível em: http://www.sm.com.br/detalhe/ultimas-noticias/pao-de-acucar-cria-divisao-imobiliaria. Acesso em: 11 set. 2016.

DURAND, C. Pourquoi les distributeurs échouent ou réussissent a l'étranger. Une analyse comparée de $l^{\prime}$ internationalisation de Wal-Mart et Carrefour. Entreprises et histoire, 2011/3 n 64, p. 118-145.

FILGUEIRAS, M. L; MELO, A; RYNGELBLUM, I. Walmart vende operação no Brasil para empresa de private equity Advent. Valor Econômico, 4 jun. 2018. Disponível em: https://www.valor.com.br/empresas/5567975/walmart-vende-operacao-no-brasil-para-empresa-de-privat e-equity-advent. Acesso em: 7 jun. 2018.

HARVEY, D. Espaços de esperança. 2 ed. São Paulo: Loyola, 2006.

IBEVAR (Instituto Brasileiro de Executivos de Varejo e Mercado de Consumo). As 120 maiores empresas do varejo, RANKING IBEVAR-FIA, 2019. 76p. Disponível em: https://www.ibevar.org.br/pesquisa/ranking-2019-IBEVAR-FIA-catalogo.pdf. Acesso em 26 dez. 2019

LEFEBVRE, H. O mundial e o planetário. Cidades, Presidente Prudente, v. 12, n. 21, p. 441-455, 2015.

LEFEBVRE, H. La production de l'espace. 4 ed. Paris: Antrophos, 2000.

MATTOS, A. Abilio Diniz estuda cobrar multa do Casino. Valor Econômico. 08 jan. 2016. http://www.valor.com.br/empresas/4383046/abilio-diniz-estuda-cobrar-multa-do-casino. Acesso em: 18 mar. 2017

MATTOS, A. Abilio Diniz quer rever aluguel de lojas e cobra multa do GPA. Valor Econômico, 19 set. 2017.

http://www.valor.com.br/empresas/5118570/abilio-diniz-quer-rever-aluguel-de-lojas-e-cobra-multa-do-g pa. Acesso em: 14 out. 2017.

MÉRENNE-SCHOUMAKER, B.; NAPPI-CHOULET, I.. Commerce et opérateurs immobiliers: um marche na voie de financiarisation. In: GASNIER, A; LEMARCHAND, N.. Le commerce dans tous ses états. Rennes: Presses Universitaires de Rennes, 2014. p. 197-204. 
MOATI, P. Modes et lieux de consommation, Territoires 2040 - Des facteurs de changement 2, Datar, n. 6, p. 27-42, 2009.

NAPPI-CHOULET, I. Externalisation d'actifs immobiliers: les contours de l'expérience européenne. Réflexions Immobilières, n. 34, p. 1-6, 2003.

NETTO, A. Carrefour aprova separação da rede Dia e diz que não vai sair do Brasil. Estadão, Economia \& Negócios. 22 jun. 2011. Disponível em: https://economia.estadao.com.br/noticias/geral,carrefour-aprova-separacao-da-rede-dia-e-diz-que-nao-va i-sair-do-brasil-imp-,735493. Acesso em: 10 jan. 2019.

PEREIRA, C. S. S. A nova condição urbana: espaços comerciais e de consumo na reestruturação da cidade - Juazeiro do Norte/CE e Ribeirão Preto/SP. 485f. Tese (Doutorado em Geografia), Programa de Pós-Graduação em Geografia, Universidade Estadual Paulista "Júlio de Mesquita Filho", Presidente Prudente, 2018.

PEREIRA, C. S. S. Comércio varejista e negócios imobiliários: o espaço como estratégia para a reprodução econômica - o exemplo do rupo Carrefour. Trabalho apresentado no VII Seminário Internacional Ciudad, Comercio y Consumo, 16 a 21 de setembro de 2019, Buenos Aires, 2019. p. 1-20.

PHILON, D. As grandes empresas fragilizadas pela finança. In: CHESNAIS, François (org.) A Finança Mundializada: razões sociais e políticas, configuração, consequências. São Paulo. Boitempo Editorial, 2005. p. 133-151

RANCIÈRE, J. Ódio à democracia. São Paulo: Boitempo, 2015.

ROLLI, C. Carrefour transformará hipermercado em shopping center em São Paulo. Folha de S. Paulo. 4 dez.

2015.

http://www1.folha.uol.com.br/mercado/2015/12/1714802-carrefour-transformara-hipermercado-em-sho pping-center-em-sao-paulo.shtml. Acesso em: 17 dez. 2016.

SCHELLER, F.; SCARAMUZZO, M. Hipermercados buscam uma nova identidade. O Estado de S. Paulo (Estadão), Economia, 1/12/2014. Disponível em: http://economia.estadao.com.br/noticias/geral,hipermercados-buscam-uma-nova-identidade-imp-, 16003 55. Acesso em: 3 mai. 2015.

SCARAMUZZO, M. Abilio Diniz tenta rever aluguel de lojas do GPA. Estadão, 3 set. 2015. Disponível em:

http://economia.estadao.com.br/noticias/negocios,abilio-diniz-tenta-rever-aluguel-de-lojas-do-gpa, 17556 87. Acesso em 19 jul. 2017.

SALOMÃO, K. Conheça o Advent, fundo que agora vai mandar no Walmart Brasil. Exame, 4 jun. 2018.

Disponível em: https://exame.abril.com.br/negocios/conheca-o-advent-fundo-que-agora-vai-mandar-no-walmart-no-bras il/. Acesso em: 7 jun. 2018.

SALTORATO, P. et al. Fusões, aquisições e difusão da lógica financeira sobre as operações de varejo brasileiro. Gest. Prod. [online]., vol. 23, n.1, p. 84-103, 2016.

SANTOS, M. Por uma geografia nova. São Paulo: Hucitec, 1978.

SANTOS, M. Sociedade e espaço: a formação social como teoria e como método. Boletim Paulista de Geografia, São Paulo: AGB, p. 81- 99, 1977.

SANTOS, M; SILVEIRA, M. L. O Brasil: território e sociedade no início do século XXI. Rio de Janeiro: Record, 2001.

VIDALON, D. Carrefour irá comprar 127 shoppings da Klepierre por 2 bi de euros. Agencia Reuters, 16/12/2013. Disponível em: http://br.reuters.com/article/businessNews/idBRSPE9BF00I20131216. Acesso em: 26 set. 2015. 
WRIGLEY, N; WOOD, S. An economic geography of globalizing retail: emergence, characteristics, contribution. In: COOK, G., BEAVERSTOCK, J., JOHNS, J., MCDONALD, F. and PANDIT, N. (eds.) The Routledge Companion to Economic Geography and International Business. London; New York. Routledge. 2018. 